\title{
Blackfly fever and dermatitis caused by Simulium kiritshenkoi: a human case report in Iran
}

\author{
Farbod Tabatabaei ${ }^{1}$, Sahar Azarmi ${ }^{2}$, Mohammad Javad Abbaszadeh Afshar ${ }^{3,4}$, Hamed $_{\text {Yarizadeh }}{ }^{3}$ and
} Sina Mohtasebi ${ }^{3 *}$ iD

\begin{abstract}
Background: Besides the considerable role of blackflies to the transmission of many disease agents, these flies considered as annoying biting pests of wildlife, livestock, poultry, and humans. There are few literature reports of blackfly fever following Simulium spp. This study describes a case of blackfly fever and dermatitis following blackflies numerous bites in Iran.

Case presentation: The present report describes a 25-year-old man that was attacked by numerous flies while fishing and camping near Namrood river in Firuzkuh County, Tehran Province, Iran. Pruritic dermatitis with marked edema appeared mainly on the hands and legs and subsequently, the patient's condition worsened with swollen lymph nodes, joints aching, and $40^{\circ} \mathrm{C}$ fever. The patient's clinical signs and symptoms were alleviated by injection of intramuscular Dexamethasone Phosphate (DEXADIC ${ }^{\oplus}$ ) $8 \mathrm{mg} / 2 \mathrm{ml}$ after $24 \mathrm{~h}$.
\end{abstract}

Conclusions: This study reported a human case with blackfly fever and dermatitis following numerous bites of Simulium kiritshenkoi, for the first time in Iran.

Keywords: Simulium, Blackfly fever, Dermatitis, Iran, Case report

\section{Background}

Blackflies or buffalo gnats (Diptera: Simuliidae) have a wide distribution around the world, consisting of more than 2300 known species in 19 genera [1]. Twenty-three species of this family have been reported from different parts of Iran [2]. Humped thorax, squat body, 11-segmented antennae and broad wings are the most prominent morphological characters of blackflies [3]. Adult females of simuliids are of medical and veterinary importance in temperate regions of the world. The most important species of these flies are in the genus Simulium, which act as vectors for Onchocerca volvulus and Mansonella ozzardi causing human onchocerciasis

\footnotetext{
* Correspondence: sina.mohtasebi@gmail.com

${ }^{3}$ Department of Medical Parasitology and Mycology, School of Public Health, Tehran University of Medical Sciences, Tehran, Iran

Full list of author information is available at the end of the article
}

and mansonellosis, in tropical and temperate regions, respectively. Moreover, they transmit pathogenic nematodes (such as Onchocerca gutturosa and Onchocerca cervicalis), viruses causing Eastern equine encephalitis and vesicular stomatitis, protozoa (the genus Leucocytozoon) to livestock and birds [3, 4]. Also, blackfly bites could cause local pain, redness, dermatitis, wounds, blackfly fever, and retropharyngeal edema in humans due to a reaction to blackfly salivary compounds [4, 5]. Blackfly fever is a systemic reaction following a blackfly bite that includes headache, nausea, fever, weakness, and swollen lymph nodes [1]. In the present study, a case of blackfly fever and dermatitis following numerous blackfly bites, is described in Firuzkuh County, Tehran Province, center of Iran.

(c) The Author(s). 2020 Open Access This article is licensed under a Creative Commons Attribution 4.0 International License, which permits use, sharing, adaptation, distribution and reproduction in any medium or format, as long as you give appropriate credit to the original author(s) and the source, provide a link to the Creative Commons licence, and indicate if changes were made. The images or other third party material in this article are included in the article's Creative Commons licence, unless indicated otherwise in a credit line to the material. If material is not included in the article's Creative Commons licence and your intended use is not permitted by statutory regulation or exceeds the permitted use, you will need to obtain permission directly from the copyright holder. To view a copy of this licence, visit http://creativecommons.org/licenses/by/4.0/ The Creative Commons Public Domain Dedication waiver (http://creativecommons.org/publicdomain/zero/1.0/) applies to the data made available in this article, unless otherwise stated in a credit line to the data. 


\section{Case presentation}

In September 2019, a 25-year-old man from Tehran province, while fishing and camping in Namrood river in Harandeh village, Firuzkuh County, Tehran Province, Iran $\left(35.7550^{\circ} \mathrm{N}, 52.7724^{\circ} \mathrm{E}\right)$ (Fig. 1) was attacked by numerous Simulium flies at early morning. After few minutes, pruritic dermatitis with considerable edema appeared in biting sites on hands and legs (Fig. 2). In the next few hours, the patient's condition aggravated in reactions to blackflies bites by appearing swollen lymph nodes, joints aching, and $40^{\circ} \mathrm{C}$ fever. The patient's clinical signs and symptoms were alleviated by single injection of intramuscular Dexamethasone Phosphate (DEXADIC $\left.{ }^{\circ}\right) 8 \mathrm{mg} / 2 \mathrm{ml}$ after $24 \mathrm{~h}$ after referring to an infectious disease specialist. However, the pruritic lesions completely healed after 1014 days with no further treatment. Meanwhile, the interview revealed that the patient had no history of allergic diseases and had not yet experienced such condition.

The flies were captured on the skin during bloodfeeding by the patient and kept in a capped container. All captured flies were brought to the Department of Medical Parasitology, School of Public Health, Tehran University of Medical Sciences for further investigations.

By investigating the morphological characteristics, the collected adult blackflies were identified as the females
S. kiritshenkoi (Fig. 3). In the female blackflies, the eyes are separated (dichoptic). While, in the males, the eyes are close together (holoptic). Tarsus of the hind leg with calcipala, no hair at the base of radius vein, two silvery grey parts at the front of the scutum, the hairy pleural membrane, strongly beak-like process on the ventral plate of the genitalia, and red or reddish-orange antennae are some morphological characters of adult male $S$. kiritshenkoi. Adult females of S. kiritshenkoi have a hairy pleural membrane, and calcipala on the tarsus of the hind leg. Scutum is black or dark grey-black with ornatum pattern. Antennae are orange-red [6].

\section{Discussion and conclusions}

Harandeh village in Firuzkuh County has a cold climate and Namrood river passes through the village and many fishermen and campers visit there for fishing and camping. Blackflies are abundant in that area. Hence, the risk of blackflies bites is of great significance. In the present study, the captured flies were identified as $S$. kiritshenkoi based on available keys.

In 1970-1980 three genera, seven sub genera and 17 species of simuliides were identified from Iran and Iraq [6]. In a complementary study in 2010-2012, 23 species of blackflies were recognized and reported [2]. Previously $S$.

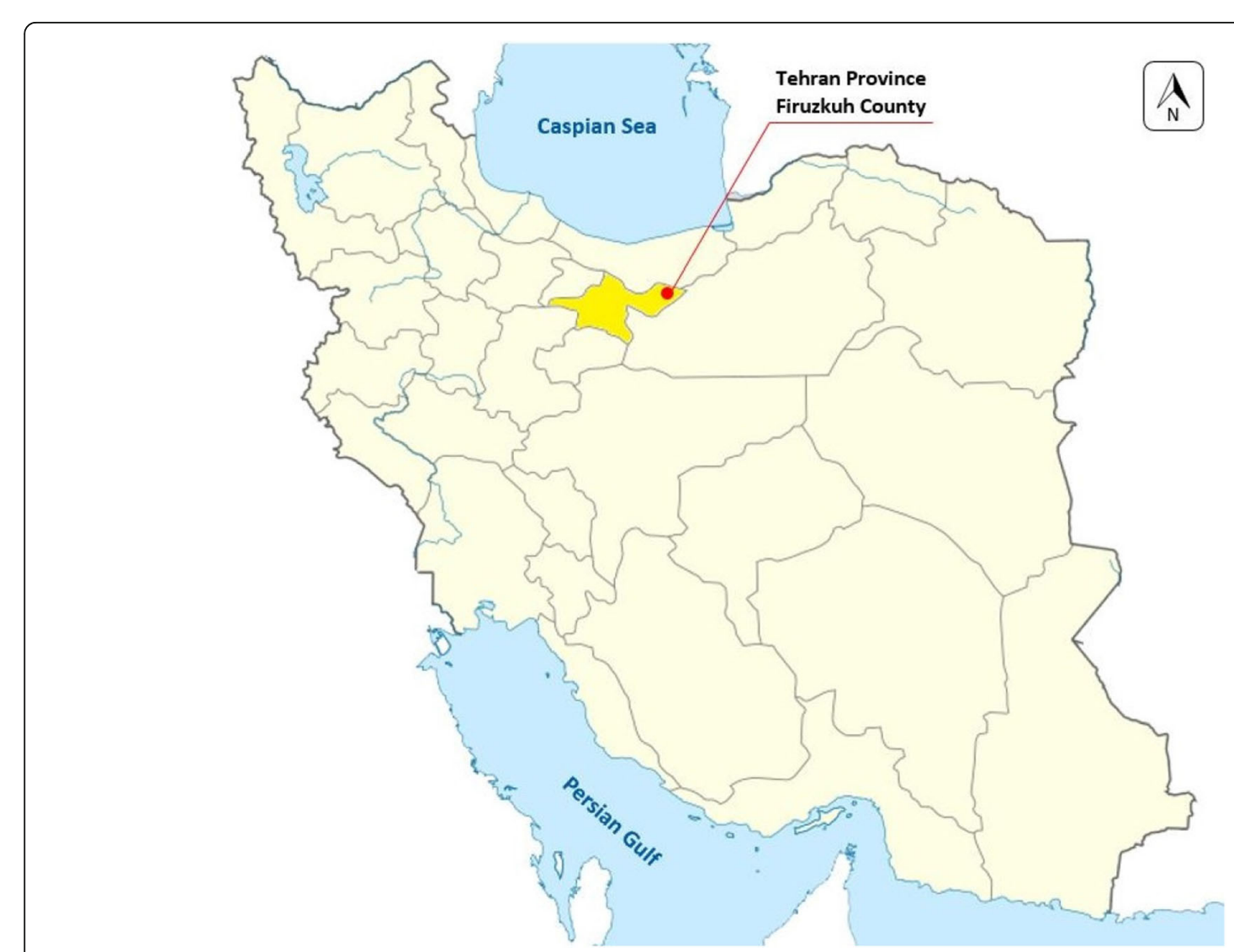

Fig. 1 Map of Iran, Firuzkuh location in Tehran Province 


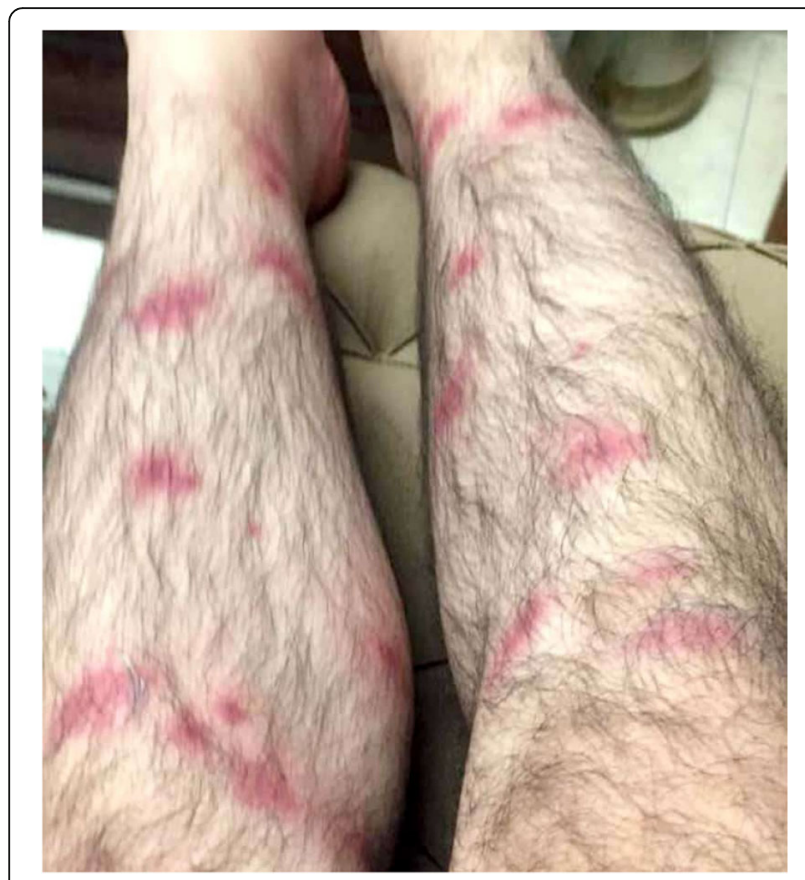

Fig. 2 The lesions on the legs. Inflammation and redness around biting sites is visible

kiritshenkoi and Simulium caucasicum have been reported from Namrood river which confirms our investigations [7].

In a study by Youssefi et al., a case of dermatitis caused by blackflies bites in a 32 year-old-man was reported in Lorestan Province, western Iran [8].

In the present study, blackfly fever and dermatitis were observed in the patient after S. kiritshenkoi bites. Blackfly fever is a systemic reaction in humans following a blackfly bite that includes headache, nausea, joints aching, high fever, weakness, and swollen lymph nodes [1].

In Japan, Watanabe described an 8-year-old boy with Kawasaki disease and retropharyngeal edema following blackflies bite [5]. Kawasaki disease, known also as mucocutaneous lymph node syndrome, causes inflammation in the walls of blood vessels throughout the body. This disease is a rare childhood disease. Rash, redness, fever, lymph nodes swelling in the neck, and irritation and inflammation of the mucous membranes are some symptoms of Kawasaki disease [9]. The Watanabe results conclude that systemic $\mathrm{T}$ cell activation due to a blackfly bites and high volume of salivary secretions may have resulted in the development of Kawasaki disease in patients. Numerous bites and injection of the salivary secretions lead to a variety of reactions from itching and local swelling to severe allergic reactions, blackfly fever or even anaphylactic shock and death [10].

As regards the veterinary importance of black fly, cases of severe dermal lesions and death in livestock following the mass attack of Simulium maegaitae have been reported in Arasbaran area in northwestern Iran [11].

Although there is no report of river blindness in Iran, a rare case of human ocular onchocerciasis caused by Onchocercia lupi has been reported [12]. The increasing human cases in Europe and the United States of America confirm the zoonotic role and importance of $O$. lupi parasite $[13,14]$.

Because of the biphasic life cycle of simuliids, including winged adults and aquatic stages, the blackfly control is extremely complex [1]. Black flies worldwide are managed primarily through the use of the bacterium Bacillus thuringiensis var. israelensis, which is aimed at the larval stage. Chemical insecticides such as permethrin are not selective and have deleterious impacts on other aquatic communities like Plecoptera and Ephemeroptera, which are considered as a vital food source for insectivorous fishes, therefore, they are used only in a few areas of the world $[1,15]$. People should avoid outdoor activity during the early morning, and evening particularly in warm weather. Also, it is suggested to wear protective clothes and repellents for personal protection.

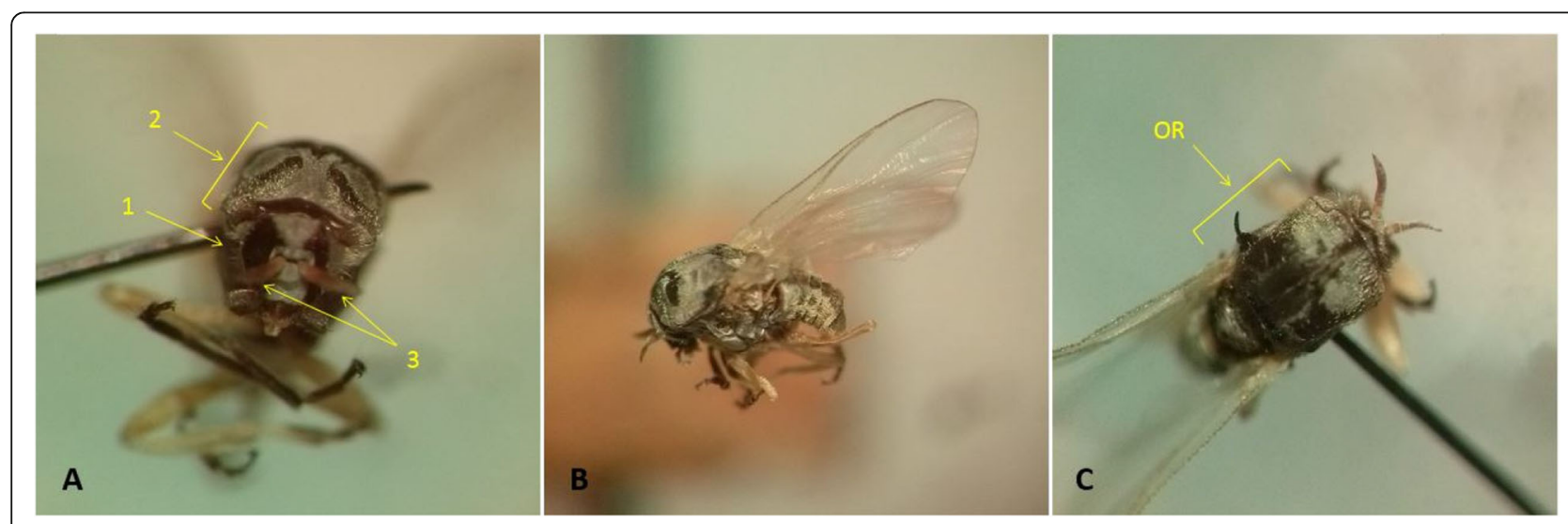

Fig. 3 Adult female Simulium kiritshenkoi. a: 1. dichoptic eyes 2. Front view of scutal pattern 3. Reddish orange antennae, b: Lateral view, c: Ornatum pattern of scutum (OR) 
In conclusion, this study reported a human case with blackfly fever and dermatitis following S. kiritshenkoi bites for the first time in Iran. According to the comprehensible medical and veterinary importance of blackflies in the transmission of diseases and their direct harms, it is worthwhile to study the species of blackflies and their distribution in Iran to facilitate appropriate preventive measures.

\section{Acknowledgments}

The authors thanks Dr. Bahareh Sedaghat for her detailed and insightful comments.

\section{Authors' contributions}

FT, SM and MJAA Writing the original draft, SA and HY identification of the species. The manuscript has been read and approved by all named authors.

\section{Funding}

The author declares that no financial fund was secured from any sources for this research work.

\section{Availability of data and materials}

All data and materials of this article are included in the manuscript

\section{Ethics approval and consent to participate}

This study was approved by the Ethics Committee of the Tehran University of Medical Sciences.

\section{Consent for publication}

We have obtained written consent from the patient for publication of their personal and clinical details and for publication of the image illustrated in Fig. 2.

\section{Competing interests}

The authors declare that they have no competing interests.

\section{Author details}

'School of Allied Medical Sciences, Iran University of Medical Sciences, Tehran, Iran. ${ }^{2}$ Department of Medical Entomology and Vector Control, School of Public Health, Tehran University of Medical Sciences, Tehran, Iran.

${ }^{3}$ Department of Medical Parasitology and Mycology, School of Public Health, Tehran University of Medical Sciences, Tehran, Iran. ${ }^{4}$ Department of Medical Parasitology and Mycology, School of Medicine, Jiroft University of Medical Sciences, Jiroft, Iran.

Received: 24 January 2020 Accepted: 4 May 2020

Published online: 15 May 2020

\section{References}

1. Adler PH, McCreadie JW. Black Flies (Simuliidae). Medical and Veterinary Entomology: Elsevier; 2019. p. 237-59

2. Khazeni A, Adler PH, Telmadareiiy Z, Oshaghi MA, Vatandoost H, Abtahi SM, et al. The black flies (Diptera: Simuliidae) of Iran. Zootaxa. 2013; 3694(1):67-74.

3. Wall RL, Shearer D. Textbook of Veterinary ectoparasites: biology, pathology and control. Second Edition ed: John Wiley \& Sons; 2008. p. 104-6.

4. Erickson T. Marquez A. Arthropod envenomation and parasitism. Wilderness Med. 2007;6:925-54

5. Watanabe T Kawasaki disease with retropharyngeal edema following a blackfly bite. Case reports in pediatrics. 2014;V (2014):Article ID 296456, 3 pages.

6. Crosskey R. A taxonomic account of the blackfly fauna of Iraq and Iran, including keys for species identification (Diptera: Simuliidae). J Nat Hist. 2002:36(15):1841-86.

7. Ardalan A, Sandjan P. Determination of black fly species in Tehran area by rearing these aquatic stages in the laboratory. Iran J Public Health. 1979:21-6.

8. Youssefi M, Aminpour A, ARAB KF. Dermatitis caused by Simulium (blackflies) bite. Iran J Parasitol. 2008;3(3):48-53.
9. Kawasaki T, Naoe S. History of Kawasaki disease. Clin Exp Nephrol. 2014; 18(2):301-4.

10. Ames I lowa Insect Information Notes. Department of Entomology. lowa State University: Academic press; 2005 [Available from: https://hortnews. extension.iastate.edu/black-fly.

11. Nikdel M, Sedghian B, Dardaie A. Simulium maegaitae and lesions caused by them in cattle in Arasbaran region. Pajouhesh Sazandegi. 2003;15(1):7-9.

12. Mowlavi G, Farzbod F, Kheirkhah A, Mobedi I, Bowman D, Naddaf S. Human ocular onchocerciasis caused by Onchocerca lupi (Spirurida, Onchocercidae) in Iran. J Helminthol. 2014;88(2):250-5.

13. Otranto D, Dantas-Torres F, Cebeci Z, Yeniad B, Buyukbabani N, Boral OB, et al. Human ocular filariasis: further evidence on the zoonotic role of Onchocerca lupi. Parasit Vectors. 2012;5(1):84.

14. Eberhard ML, Ostovar GA, Chundu K, Hobohm D, Feiz-Erfan I, Mathison BA, et al. Zoonotic Onchocerca lupi infection in a 22-month-old child in Arizona: first report in the United States and a review of the literature. Am J Trop Med Hygiene. 2013;88(3):601-5.

15. Hua J, Relyea R. The effect of a common pyrethroid insecticide on wetland communities. Environ Res Commun. 2019;1(1):015003.

\section{Publisher's Note}

Springer Nature remains neutral with regard to jurisdictional claims in published maps and institutional affiliations.

Ready to submit your research? Choose BMC and benefit from:

- fast, convenient online submission

- thorough peer review by experienced researchers in your field

- rapid publication on acceptance

- support for research data, including large and complex data types

- gold Open Access which fosters wider collaboration and increased citations

- maximum visibility for your research: over $100 \mathrm{M}$ website views per year

At BMC, research is always in progress.

Learn more biomedcentral.com/submissions 